Note

\title{
LEGAL ANOMALIES WITHIN HUMAN RIGHTS IMPLEMENTATION IN COURT PROCEEDINGS: UKRAINIAN HERITAGE AND PERSPECTIVES
}

\author{
Mykhailo Ryazanov, Hanna Chuvakova and Suliko Piliuk \\ Miriazmr@gmail.com \\ 0000-0003-0404-2841 \\ chuvakovaa@gmail.com \\ 0000-0001-6380-1233 \\ pilyuk sv@onu.edu.ua \\ 0000-0001-5419-024X
}

Summary: 1. Introduction. - 2. General Specific Causes of Legal Anomalies in the Implementation of Individual Rights in Court. - 3. Abuse of Procedural Rights as a Distortion of the Realisation of Rights. - 4. Simplified Action (Written) Proceedings as a Legally Established Anomaly. - 5. The Legal Anomaly of the Lack of Unity of Judicial Case-law. - 6. Conclusions.

To cite this note: M Ryazanov, H Chuvakova, S Piliuk 'Legal anomalies within human rights implementation in court: Ukrainian heritage and perspectives' 2021 4(12) Access to Justice in Eastern Europe 90-103. D0l: https://doi. org/10.33327/AJEE-18-4.4-n000086

To link to this note: https://doi.org/10.33327/AJEE-18-4.4-n000086

Submitted on 27 May 2021 / Revised 30 Aug 2021 / Revised 14 Sept 2021 / Approved 18 0ct 2021

Published online: 01 Nov $2021 \quad$ View data

Submit your article to Access to Justice in Eastern Europe

\section{CONFLICTS OF INTEREST}

The authors declare no conflict of interest of relevance to this topic. Although one of the authors serves at the same institution as one of the editors of AJEE, which may cause a potential conflict or the perception of bias, the final decisions for the publication of this article, including the choice of peer reviewers, were handled by the editors and the editorial board members, who are not affiliated with the same institution.

\section{DISCLAIMER}

The authors declare that they were not involved in any state bodies, courts, or any other organisation's activities related to the discussed views and case-law. 


\section{ACKNOWLEDGEMENTS}

The authors would like to express their gratitude to the reviewers and editors of the journal and to the English editor, Sarah White.

\section{CONTRIBUTORSHIP}

The authors contributed jointly to this study and its results. Mykhailo Ryazanov and Hanna Chuvakova are responsible for the exploration of sources and for writing; Hanna Chuvakova and Suliko Piliuk are both responsible for the analysis and interpretation; all the co-authors take responsibility for the content of the paper. The content of the paper was translated with the participation of third parties under the authors' oversight. 


\section{LEGAL ANOMALIES WITHIN HUMAN RIGHTS IMPLEMENTATION IN COURT: UKRAINIAN HERITAGE AND PERSPECTIVES}

\section{Ryazanov Mykhailo}

Candid. of Legal Science (equiv. to Ph.D.),

Associate professor of the Department of General Theory of Law and State

National University 'Odessa Law Academy', Ukraine

Miriazmr@onu.ua

0000-0003-0404-2841

\section{Chuvakova Hanna}

Candid. of Legal Science (equiv. to Ph.D.),

Associate professor of the Department of General Theory of Law and State

National University ‘Odessa Law Academy’, Ukraine

chuvakovaa@onu.ua

0000-0001-6380-1233

\section{Piliuk Suliko}

Candid. of Legal Science (equiv. to Ph.D.),

Associate Professor of the Department of Constitutional Law

and Justice Odesa I.I. Mechnikov National University

pilyuk_sv@onu.edu.ua

0000-0001-5419-024X

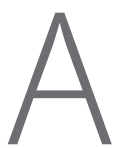

bstract The law is a regulator of relations based on an orderly, generally accepted system of ideas and norms for the behaviour of subjects in a particular relationship. A large number of regulations, which are an external reflection of the content of law, sets the boundaries of such behaviour, but under the influence of relevant factors that have a subjective and/or objective nature, there are cases of deviation from generally accepted regulations, the so-called legal anomalies that occur in the exercise of a person's rights in court.

This article contains an analysis of current legal anomalies that may arise in the exercise of a person's procedural rights in the administration of justice, given the reasons that provoke their occurrence. Both legal anomalies related to the subject of realisation of rights in court and anomalies that indirectly affect the possibility and completeness of such realisation were subject to research. The authors assessed the phenomenon of abuse of law, legal nihilism of the participants in the process, inconsistencies of judicial practice, etc., in terms of classifying such phenomena as legal anomalies. The possibility of recognising a legal anomaly at the legislative level (abuse of law) and the transformation of a legal anomaly into a rule of procedural law (written proceedings) is investigated. Variants of vulnerabilities of the modern mechanism of administration of justice are offered, where there is a high probability of emergence of new legal anomalies in the sphere of realisation of the rights of the person at protection by a court of the broken, unrecognised, or disputed rights.

Keywords: legal anomaly, deviation from the norm, abuse of law, legal nihilism, adversarial principle, unity of judicial practice 


\section{INTRODUCTION}

Human life is associated with a large number of rights and responsibilities that arise and are realised within the legal relationship, i.e., in interaction with the rights and responsibilities of other participants in such relationships. Therefore, there is a risk of violation, non-recognition, or challenge of those or other human rights. The existence of this risk corresponds to the right at the legislative level (both national and international law) to protect the rights and legitimate interests, in particular, that of the court. Thus, Part 1 of Art. 55 of the Constitution of Ukraine declares that human and civil rights and freedoms are protected by a court, ${ }^{1}$ and Art. 6 of the Convention for the Protection of Human Rights and Fundamental Freedoms of 1950 enshrines the right to a fair trial. ${ }^{2}$

It is worth noting that when a person applies to the court, he/she has an additional set of procedural rights and obligations that are directly related to the fact of applying to the court and the subsequent implementation of court proceedings. Given the peculiarities of the emergence and exercise of such rights, the manifestation of legal anomalies in the implementation of human rights in court is no exception in practice.

A legal anomaly is understood as a kind of obstacle in the legal regulation of social relations. A legal anomaly is a deviation from the general law and the normal formation and development of social relations due to various factors of objective and subjective order. ${ }^{3}$

Thus, a legal anomaly is beyond the content of law and the necessary connections of its elements and forms, which are generally random and unforced because the existence of such anomalies does not meet the main purpose of law and its objective logic and is not the result natural conceptual manifestations of law as a regulator of social relations. Anomalies that exist practically in law are called legal anomalies but have nothing to do with the implementation of the purpose and reflection of the content of the law itself.

When characterising the essence of legal anomalies, it should be noted that legal anomalies are an objective reality, but such a reality is a deviation from the substantive line of law, the goals of legal will, the mandatory sequences and structure of law, and the natural connections between legal phenomena and processes.

The consequences of such anomalies can be a violation of the rights and interests of the subjects of legal relations, violation of other legal norms, increasing distrust in the judiciary, distortion of the administration of justice, and so on. Given these possible consequences, it is important to identify and study legal anomalies in the implementation of individual rights in court, which are the most common and pose a real threat to the existing legal reality. That is why the research topic is relevant.

\section{GENERAL SPECIFIC CAUSES OF LEGAL ANOMALIES IN THE INDIVIDUAL'S RIGHTS IMPLEMENTATION IN COURT}

Legal anomalies, like any phenomenon in law, arise for certain reasons, which can theoretically be divided into external and internal. External grounds for anomalies arise in

1 Constitution of Ukraine 28 June 1996 no 254K/96-BP <https://zakon.rada.gov.ua/laws/ show/254\%D0\%BA/96-\%D0\%B2\%D1\%80\#Text> accessed 14 September 2021.

2 Convention for the Protection of Human Rights and Fundamental Freedoms Council of Europe 1950 $<$ https://www.echr.coe.int/documents/convention_eng.pdf> accessed 11 September 2021.

3 Yu Oborotov, V Zavalniuk, V Douduchenko, Creativity of common law jurisprudence (Phenix 2015). 
the interaction of law as a special form of purposeful substantive activity with other forms of social life, which simultaneously act as catalysts for certain legal needs, generating and consolidating the rule of law itself and factors of preconditions for legal anomalies within this norm. Such factors are usually changes in the economic, political sphere, and so on.

For example, quarantine and restrictive anti-epidemic measures to prevent the spread of acute respiratory disease COVID- 19 caused by the SARS-CoV-2 coronavirus in Ukraine have led to legal anomalies in the form of gaps in legal regulation related to direct involvement cases in court. ${ }^{4}$ Even though the procedural legislation of Ukraine provides for the possibility to participate in court hearings by video conference, it is not an exception to violate the right of a party to participate in a court hearing due to lack of court opportunity to ensure such participation remotely.

The formation of such a deviation from the general obligation to ensure a person's right to be present at a court hearing is caused by the fact that the legislator provided that a court hearing by video conference can be held, provided the court has the appropriate technical capacity but did not specify what should be considered such a technical possibility. As a result, in practice, there is a situation in which the court, instead of postponing the date and time of the hearing, refuses a person to participate in the hearing by videoconference, and therefore holds such a hearing without his participation, only because the date and time of the trial meetings free technical devices to ensure its holding are absent. That is, the court has the technical possibility to hold a court hearing using video, but at the appointed date and time, there is no such possibility.

Thus, under the influence of the relevant external factor on the basis of existing gaps in the law (legal anomaly of rulemaking), there are legal anomalies of law enforcement in the form of defective legal facts - making a substantively incorrect decision. In turn, defective legal facts, as types of legal anomalies, should be understood as a fact of legal nature with existing shortcomings. A legal fact is defective in cases when its features do not correspond to the model enshrined in the hypothesis of a legal norm - a legal criterion. The defect of a legal fact should be considered the presence in it of such signs that indicate a significant change in its content - the social criterion.

Undoubtedly, as mentioned above, legal anomalies are related to law enforcement, i.e., they arise in the process of subjective interpretation of the relevant rule of law and its use. Thus, internal factors are important for the occurrence of a legal anomaly. Thus, all elements of the formation of the content of law are the products of consciousness and will of specific people, each of which has a certain level of knowledge about the world, including legal phenomena and processes, occupies a certain place in society and social relations, defends their own life interests, etc. Lack of understanding of the relevant processes and lack of certain skills to participate in them lead to the fact that activities in the protection of their rights in court by the person are chaotic, often by trial and error. Legal activity, in this case, generates a lot of legal anomalies, which are included in the legal mechanisms.

Thus, legal anomalies in some cases are related to the subjective vision and attitude to a particular legal phenomenon, which sometimes have the character of legal nihilism. Currently, there is no single approach to the interpretation of legal nihilism. Within the usual approach, which is prevalent, legal nihilism is seen as a destructive social phenomenon, the

$4 \quad$ See the special issue of AJEE related to the Covid-19 and its impact of judiciary in Ukraine: I Izarova 'About Special Double Issue 2-3/2020, Justice Under Covid-19 Pandemic' (2020) 2-3 (7) Access to Justice in Eastern Europe 4-5; O Rozhnov 'Towards Timely Justice in Civil Matters Amid the COVID-19 Pandemic' (2020) 2-3 (7) Access to Justice in Eastern Europe 100-114; O Kaplina, S Sharenko 'Access to Justice in Ukrainian Criminal Proceedings During the COVID-19 Outbreak' (2020) 2/3 (7) Access to Justice in Eastern Europe 115-133 and others. 
essence of which is a negative attitude towards law, lack of faith in its potential to solve existing problems, and ignoring the requirements established by law.

Representatives of another innovative approach try to explain the essence of legal nihilism through the imperfection and inefficiency of the law itself. ${ }^{5}$ However, according to the authors of this study, it is not necessary to explain the distortion of the perception of law with the help of an innovative approach, as such an approach eliminates the need to fight and combat legal nihilism, as it is impossible to change the essence of law. In practice, the elimination of the emergence and formation of manifestations of legal nihilism is an important task, the solution of which can lead to effective counteraction to other manifestations of legal anomalies.

\section{ABUSE OF PROCEDURAL RIGHTS AS A DISTORTION OF THE REALISATION OF RIGHTS}

In the context of realisation of the rights of the person in court, it is necessary to examine a legal anomaly in the form of abuse of the procedural right, ${ }^{6}$ through which the internal factor of the occurrence of an anomaly is clearly expressed.

EV Vaskovsky interprets the abuse of procedural law as an inadmissible exercise of a certain right, which opposes the correct, timely consideration of the case and the court's decision on it or leads to an unfair result for the other party. ${ }^{7}$ AA Yudin understands the abuse of procedural rights as a special form of civil procedural offence, i.e., intentional dishonest actions of participants in civil proceedings, accompanied by violation of the conditions of subjective procedural rights and carried out only with the appearance of such rights associated with the deception of known circumstances of the case, in order to limit the possibility of realisation or violation of the rights of other persons involved in the case, as well as to prevent the court from proper and timely consideration and resolution of civil cases involving measures of civil coercion. ${ }^{8}$

However, it is difficult to agree with Yudin's opinion because the illegal nature of the abuse of rights is not always clearly expressed. At the same time, abuse of rights cannot be considered lawful behaviour, as the latter may harm the rights and interests of others. Thus, abuse of law is a phenomenon of either legal behaviour (here, the criterion of evaluation is the letter of the law) or illegal behaviour (here, the criterion of evaluation is the spirit of law).

The illegality of conduct in the case of abuse of rights is not so much a contradiction of the law as the rights and interests of individuals. Abuse of the right should be attributed to legal conduct, which may become illegal or become an offence, but not always. ${ }^{9}$

$5 \quad$ A Zriachkin, 'Nihilism in law: causes and ways of solution' (PhD thesis, Saratov 2007) 11.

6 SO Kravtsov, 'Some aspects of abuse of procedural rights in enforcement proceedings' (2019) 6 Legal scientific electronic journal 121-125; SA Kravtsov, 'Abuse of procedural rights by the parties to enforcement proceedings: Theoretical and practical aspects' (2018) 4 Bulletin of the civil process 174206; K Gajda-Roszczynialska, 'Abuse of procedural rights in Polish and European civil procedure law and the notion of private and public interest' (2019) 2 (3) Access to Justice in Eastern Europe 53-85; I Izarova, T Korotenko, 'Prevention of Procedural Rights Abuse: A New Experience of Ukrainian Judges' Polski Proces Cywilny (Civil Procedure of Poland)' (2019) 1 Access to Justice in Eastern Europe 24-33.

$7 \quad$ E Vaskovsky, Course of civil procedure, Vol 1 (Izd. No. Bashmakov 1997) 432.

$8 \quad$ A Yudin, 'Abuse of rights in civil proceedings' (PhD dissertation, SPb. 2009) 49.

9 DO Tikhomirov, NP Kharchenko, 'Abuse of law as a deviation of lawful behavior' (2016) 1 Scientific Bulletin of Uzhhorod National University, series: Law 27-28. 
Obviously, abuse of rights must be considered a complex legal phenomenon. On the one hand, the principle of prohibition of abuse of rights can be considered as one of the forms of manifestation of imperativeness in civil procedural law. The content of this prohibition is an indication of the legal inadmissibility of a certain course of conduct, which, however, is possible. According to Art. 44 of the CPC of Ukraine, this legal restriction is reflected in the form of the principle of the inadmissibility of abuse of rights, according to which litigants and their representatives must exercise procedural rights in good faith. Therefore, the abuse of their procedural rights consists of their unfair realisation. The term 'abuse of procedural law', in its literal sense, means the use of law for evil, in cases where the authorised entity has a subjective right, acts within it, but does any harm to the rights of other entities or society as a whole. ${ }^{10}$

In any case, the abuse of rights is a deviation from the normal behaviour of the subject of the proceedings and is contrary to the essence of the rights abused by the person, i.e., it is regarded as a legal anomaly. As a rule, abuse of law manifests itself in the form of defective legal facts, which were discussed above.

For example, a person has the right to seek the protection of his or her violated, disputed, or unrecognised rights in court. At the same time, the procedural legislation establishes the requirement that the plaintiff (the person who applied for protection) should not file another claim (claims) against the same defendant (defendants) with the same subject and on the same grounds. In practice, there are many situations when the plaintiff, having changed the qualification of the disputed legal relationship, files two or more lawsuits against the same defendant, with the same subject and grounds in courts of different jurisdictions, thus doubling the chance to achieve the desired result.

Examples of legal anomalies in the form of abuse of law are the submission by the parties of an excessive number of unnecessary applications and motions to be considered by a judge, the collection and presentation of inadequate evidence, and the involvement of persons who have no interest in resolving the case.

It is worth noting that abuse of law as a legal anomaly has long been known in legal practice and theory. However, quite recently, the legacy of these anomalies has been embodied in procedural law in the form of a direct ban on such actions. Thus, by amending the procedural legislation of Ukraine in 2017, the legislator established the basis for combating legal anomalies in the form of abuse of rights, providing the court with tools to combat abuse of rights.

This situation can be considered indicative because, as a rule, the existence and recognition at the legislative level of certain legal anomalies are rare, which in turn complicates the process of combating and further eradicating the legal anomaly as a legal phenomenon.

At present, procedural legislation, in addition to criminal procedure, provides for the right of the court to classify the relevant actions of the participants in the proceedings as an abuse of procedural rights and to take the necessary measures to prevent and further eliminate such actions. In particular, the list of such measures includes the exercise by the court of the right

10 I Lukina, Abuse of procedural rights in the civil process of Ukraine. Problems of civil law and process: materials of scientific practice' in conf. dedicated in memory of Prof. OA Pushkin (22 May 2010) (University of Internal Affairs 2010) 363; OD Korol, 'Prevention of abuse of procedural rights and encouragement of the parties to conscientious behavior' (2020) 19 (1) University scientific notes. Khmelnytsky 117-127. DOI: https://doi.org/10.37491/UNZ.73.10; S Kravtsov, 'Enforcement proceedings as a final part of the trial in the light of the case law of the European Court of Human Rights and counteraction to abuse of procedural rights of participants in enforcement proceedings' (2020) 112 Bulletin of Taras Shevchenko National University of Kyiv. Legal sciences 36-43. DOI: https: doi. org/10.17721/1728-2195/2020/1.112-7; DD Luspenyk, 'Abuse of procedural rights: legislation, methods of detection and ways to counteract' (2015) 6 Journal of Civil and Criminal Procedure 150-171. 
to leave the relevant application or petition without consideration, to impose a fine, and to raise the issue of disciplinary liability of a lawyer or prosecutor.

However, at first glance, a successful resolution of the legal anomaly may result in other legal anomalies, as the court classifies the conduct of a party to the category of abuse of procedural law as quite subjective due to the lack of criteria for assessing such conduct. Thus, in the case of abuse of subjective law, the behaviour of the subject of law is to create a situation that only has the appearance of lawful, based on the provisions of the law, while proving the abuse of subjective law is a difficult task or simply impossible for several reasons.

First, the main feature of the abuse of procedural rights is that the acts that constitute the abuse are committed on a completely legal basis from the outside.

Secondly, the mechanism of abuse of procedural rights is related to a person's desire to obtain a certain legal result (for example, to suspend the proceedings, adjourn the hearing, etc.), in connection with which the latter commits procedural actions (inaction), externally very similar to the legal facts associated with the occurrence of the desired results.

And the third problem is that in essence and content, these actions are completely artificial, like a feigned agreement in civil law, which is committed only to cover another agreement. That is, from the point of view of functionality, such actions are simply an imitation.

Thus, it is almost impossible to immediately establish signs of abuse in the actions of a participant in the process. Therefore, a significant role in eliminating this legal anomaly is given to the inner conviction and experience of the judge.

According to the authors, another way to combat the abuse of procedural rights can be considered the establishment of the so-called lawyer's monopoly. Thus, part 4 of Art. 131-2 of the Constitution of Ukraine stipulates that only a lawyer represents another person in court, as well as protection from criminal charges. Indeed, the admission of persons with relevant legal education, knowledge, and experience to the state in obtaining the right to practice law to represent others in court should significantly increase the professionalism of the administration of justice, thereby minimising the possibility of legal anomalies, in particular in the form of abuse of rights. However, there is no good reason to consider such a trend successful.

As already mentioned, legal anomalies are formed as a result of law enforcement activities, in connection with which it is worth noting that of great importance for their formation is not only the legal culture of society as a whole but also professional legal culture - the level of legal development and understanding of those people who are tasked with identifying the legal needs of society, forming legal norms, ensuring the proper implementation of the rights and responsibilities of litigants, interpreting and applying the rule of law, ensuring their positive dynamics, etc. If the shortcomings of the general legal culture lead to anomalies of private order, the low level of professional legal culture will result in the emergence and spread of legal anomalies of a general systemic nature, which in turn can lead to the deformation of certain elements of law and its devaluation as a regulator of public relations. Thus, a set of legal anomalies in a professional legal culture can lead to a global legal nihilism of destructive action.

\section{SIMPLIFIED ACTION (WRITTEN) PROCEEDINGS AS A LEGALLY ESTABLISHED ANOMALY}

The differentiation of general claims and simplified claims should also be considered as legislative consolidation of a legal anomaly. In this case, the legal anomalies, which are enshrined in law and are thus not a deviation from the norm, should be considered the most simplified litigation without summoning the parties, i.e., written proceedings 
in which the case is considered on the basis of written documents submitted by participants. ${ }^{11}$

The court's obligation to create conditions for the persons involved in the case to provide a comprehensive, fair, complete, and objective clarification of the circumstances of the case is carried out through specific procedural actions, one of which is to hold a court hearing. Even before the reform of procedural legislation in $2017,,^{12}$ consideration of the case in civil proceedings provided that the participants in the process had the opportunity to take part in such proceedings during the court hearings. This prescription provided the basic idea of further realisation by the person-participant of the process of the procedural rights, some of which can be realised in full only at personal (or through the representative) participation of the person at the consideration of the case. In this case, we are talking about full support of the adversarial principle, which is implemented through the opportunity to participate in court hearings, examination of evidence, asking questions to other participants, as well as witnesses, experts, and specialists, providing court explanations, presenting their arguments, considerations on issues that arise during the trial, and objections to the statements, motions, and arguments of others, etc. Thus, prior to the adoption of procedural codes of civil, commercial, and administrative proceedings, a person's right to participate in court hearings was not enshrined in law, as it was already the basis for consideration of the case. Currently, the above codes separately enshrine the right of a person to participate in court hearings unless otherwise provided by law.

According to the author, the establishment of the possibility of consideration of cases without the participation of the parties can be regarded as a deviation from one of the basic principles of justice - the principle of adversarial proceedings - influence the decision. It is the adversarial principles of the process that determine the motivation of the conduct of litigants, such as the parties in court because the outcome of the dispute depends entirely on their activity. There is no doubt that the party to the process will try to reach a positive solution to the dispute, using all the rights granted to it by current legislation. At the same time, the adversarial nature of the parties in the trial is a guarantee of the efficiency of the proceedings.

However, due to the consolidation of written proceedings at the legislative level, the perception of the role of participants in court hearings is likely to change over time, so there is a chance of overestimating written proceedings as a legal anomaly.

A legal anomaly that causes a lot of negative consequences is the lack of a unified approach of judges to address similar issues. In this context, it is not a question of making diametrically different decisions or the absence of the same case law but of making intermediate decisions that will further affect the administration of justice.

11 For more on changes of the general and simplified action procedure, see IO Izarova, YuD Prityka, 'Simplified litigation of civil proceedings of Ukraine: Challenges of the first year of application in judicial practice' (2019) 145 Problems of legality 51-67; A Lesko, 'Insignificance of cases of civil jurisdiction as a criterion for their consideration in simplified claim proceedings and refusal to open cassation proceedings' High Council of Justice, Kyiv, 30 November 2017, <http://www.vru.gov.ua/ mass_media/998> DATE ACCESSED; OI Uhrynovska, 'Simplified claim proceedings: Features of legislative regulation' in Minor disputes: European and Ukrainian experience of resolution: coll. Science, etc., participants of the international scientific-practical conf., Kyiv, 23-24 November 2018 (Kyiv 2018) 187-192. For more on small claims procedure in other states, see I Izarova, R Fleiszar, V Vebraite, 'Access to Justice in Small Claims Procedure: Comparative Study of Civil Procedure in Lithuania' (2019) 9 (1) Poland and Ukraine International Journal of Procedural Law 97-117; DA Korol, 'Simplified civil proceedings in different European countries: a comparative description' (2020) 1 Journal of Kyiv University of Law 225-228. DOI: 10.36695 / 2219-5521.1.2020.45.

12 The Law of Ukraine 'On Amendments to the Commercial Procedure Code of Ukraine, Civil Procedure Code of Ukraine, Code of Administrative Procedure of Ukraine and other legislative acts' No 2147-VIII [2017] Vidomosti of the Verkhovna Rada 48/436 < 
Due to changes in procedural legislation, in particular, administrative proceedings of Ukraine, a cassation appeal against a court decision is generally filed only in the case of consideration of the case by previous courts in the general claim procedure. According to para. 2 of part 5 of Art. 328 of the Code of Administrative Procedure of Ukraine, these proceedings are not subject to cassation court decisions in cases of minor complexity and other cases considered under the rules of summary proceedings (except for cases that under this Code are considered under the rules of general proceedings), except in cases where:

a) the cassation appeal concerns the issue of law, which is fundamental for the formation of a unified law enforcement practice;

b) a person who files a cassation appeal, in accordance with this Code and is deprived of the opportunity to refute the circumstances established by the appealed court decision when considering another case;

c) the case is of significant public interest or is of exceptional importance for the party to the case who files a cassation appeal;

d) the court of first instance erroneously assigned the case to the category of cases of insignificant complexity. ${ }^{13}$

Thus, the legislator gives the Court of Cassation within the Supreme Court in deciding the opening of proceedings in a case considered in summary proceedings the right at its discretion to consider the need to accept the complaint and open cassation proceedings given the merits of one or more cassation appeal for the reasons specified in the paragraph above.

At the same time, as practice shows, it is not uncommon to make different decisions on the opening of proceedings subject to cassation appeals with identical justification of the need for such opening in similar legal relations, which the courts of previous instances considered in summary proceedings. Refusal to initiate cassation proceedings cannot be considered illegal in this case, as the decision is based solely on the internal conviction of the judges of the respective panels, but in fact, creates a situation of unfounded denial of access to justice, i.e., there is a legal anomaly that prevents a person from procedural rights.

It is difficult to resolve this legal anomaly, as the procedural legislation does not allow to appeal the refusal to open proceedings by the Court of Cassation, which could show a different view of the situation by the panels of judges of the court and develop the same mechanism for resolving this issue.

\section{THE LEGAL ANOMALY OF THE LACK OF UNITY OF JUDICIAL CASE-LAW}

The legal anomaly in the form of contradictory and competing judicial practice has an even more destructive effect on the administration of justice, especially within the framework of the exercise of their procedural rights by individuals. ${ }^{14}$ Although in Ukraine, judicial precedent is not an officially recognised source of law, the mechanism of justice is built partially on the basis of legal opinions adopted by the highest court in the judicial system of Ukraine, which ensures the stability and unity of judicial practice - the Supreme Court.

Adherence to the principle of unity of judicial practice should be understood as the beginning, the idea that ensures the courts in the judiciary uniform application of regulations and their

13 Кодекс адміністративного судочинства України: Закон України від 06.07.2005 № 2747-IV. <https:// zakon.rada.gov.ua/laws/show/2747-15\#Text> accessed 14 September 2021.

14 TA Tsuvina, 'Unity of judicial practice as an element of legal certainty: the approach of the European Court of Human Rights' (2019) 146 Problems of law 63-74. DOI: https://doi.org/10.21564/2414990x.146.175598 
interpretation, carried out by higher judicial bodies in resolving court cases. The principle of unity of judicial practice, which is supported by higher judicial bodies, reduces risks in the interpretation and application of legal norms, ensures the unity of judicial practice developed by higher judicial bodies, removes uncertainty, and creates consistency in the application of rules by lower courts. ${ }^{15}$

However, in practice, it is not uncommon for the Supreme Court to adopt completely opposite in content legal conclusions on the application of the same rule of law, which significantly complicates further decision-making in such legal relations. Such a legal anomaly is also observed regarding issues related to the exercise of a person's rights in court.

For example, consider the legal position of the Supreme Court on the application by courts of the provisions of Arts. 256, 261 of the Civil Code of Ukraine when determining the beginning of the statute of limitations in legal relations governed by Art. 388 of the Civil Code of Ukraine, ${ }^{16}$ when the person learned/or could learn about the violation of his/her right, i.e., from the moment of disposal of property or use, or from the moment when the person learned/or could learn about the violation of his/her right by acquiring property by the person who has the property at the time filing a lawsuit.

Thus, the Commercial Court of Cassation of the Supreme Court in the decision of 21 May 2019 in case no. 911/2817/17 noted that the state's ownership of the disputed land was violated when the land was removed from state ownership to the possession of another person, not at the time of concluding the next transaction on the alienation of land and not from the entry into force of a court decision confirming the illegality of disposal of the disputed land and violation of state ownership, and the beginning of the statute of limitations coincides with the prosecutor's claim in such a case. ${ }^{17}$

Thus, there are contradictory positions in the case law of courts of cassation of different jurisdictions on the beginning of the statute of limitations, which significantly affects the direct ability of a person to seek protection in court, and thus affects the possibility of the further exercise of his/her procedural rights. The solution to this legal anomaly may be the presence in the court of the right to deviate from the previously stated positions of the Court of Cassation.

It is important that the court has the right to deviate from the legal position set out in the conclusions of the Supreme Court of Ukraine while citing the relevant reasons. That is, the Supreme Court of Ukraine, having previously made a decision or legal conclusion, may further depart from it. According to Ya. Romaniuk, the Supreme Court of Ukraine has the right and should depart from such a conclusion (decision) if it considers that it has previously made a mistake. However, the Supreme Court of Ukraine should not conceal the preliminary justification of its legal opinion. The judge must carefully explain changes in practice and motivation for moving in another direction. ${ }^{18}$ Deviation of the Supreme Court

$15 \quad$ NM Parkhomenko, 'Unity of judicial practice as a component of legal regulation. Theory and history of state and law' (2020) Philosophy of law 26.

16 Civil Code of Ukraine: Law of Ukraine of 16 January 2003 no 435-IV <https://zakon.rada.gov.ua/laws/ show/435-15\#Text> accessed 14 September 2021.

17 Resolution of the Commercial Court of Cassation of the Supreme Court of 21 May 2019 in case no $911 / 2817 / 17$ <https://reyestr.court.gov.ua/Review/82068102> accessed 14 September 2021; Resolution of the Civil Court of Cassation of the Supreme Court of 16 August 2018 in case no 711/802/17 <https:// reyestr.court.gov.ua/Review/75975948> accessed 14 September 2021; Resolution of the Civil Court of Cassation of the Supreme Court on 06 June 2018 in case no 520/14722/16-ts <https://reyestr.court.gov. ua/Review/74927263> accessed 14 September 2021.

18 Ja Romanyuk, 'Ensuring the unity of judicial practice by the Supreme Court of Ukraine: the reform needs to be continued' (The newspaper of Ukrainian lawyers 'Legal practice' 15 March 2013) <https://www.viaduk.net/clients/vsu/vsu.nsf/6b6cle2e6ad3e2fcc225745c0034f4cc/ 6d8ae15d52eb146dc2257b71003f884b/\$FILE/5-9_str.pdf> accessed 14 September 2021. 
from its own preliminary opinion will not eliminate the legal anomaly of differences in caselaw but will reduce the number of such contradictory positions, which in turn will ensure the level of unity of case law at least at the average level.

Currently, the mechanism of judicial proceedings is undergoing many changes, which is reflected in the implementation of procedural rights of persons in court, in connection with which it is difficult to predict possible legal anomalies in these legal relations. At the same time, it can be assumed that in the future, a vulnerable field for the emergence of legal anomalies will be the introduction of various elements associated with the rapid development of digital technologies. Thus, the list of subjects for detailed study to prevent possible legal anomalies includes the Unified Judicial Information and Telecommunication System, namely, one of its modules, 'Electronic Court', through which subjects can sue and receive procedural documents. In addition, according to the author, the settlement of a dispute with the participation of a judge is also favourable for the occurrence of legal anomalies.

In fact, it is impossible to identify trends in the occurrence of legal anomalies in the future, as the nature of such anomalies is purely practical and does not have backed regulations. As noted above, there is currently no common vision of legal anomalies, so any phenomenon in the legal field can be considered an anomaly, depending on whether the entity analysing the phenomenon, the latter of which contains signs of deviation from the established perception of particular legal phenomena.

At the same time, the most effective counteraction to existing legal anomalies and prevention of their occurrence in the future in the field of realisation of individual rights in court is strict observance of procedural rights provided by law by all participants in the process of justice.

\section{CONCLUSIONS}

Legal anomalies in the exercise of a person's rights in court are not new to the legal reality, but the stage of reforming the administration of justice, which is gradually taking place over time, creates a favourable environment for new anomalies that were not known before, as well as strengthening known anomalies. Thus, for each stage of activity, in the process of which one or another element of the content of law is formed, it is possible to separate special anomalies caused by both external and internal factors.

The rapid development of modern society necessitates the improvement of existing legal regulations to correct the distortions that occur against the background of such development and to bring the legislation in line with the challenges and needs of society. The existence of legal anomalies makes it possible to identify weaknesses in the existing mechanism of exercising one's rights in court proceedings and analyse the nature of such anomalies and the reasons for their occurrence, thus enabling a mechanism to counteract existing anomalies and prevent others in the future.

The study showed a different attitude of the Ukrainian legislator to the problems of anomalies in the exercise of human rights in court, which in one case manifests itself in consolidating the mechanism to combat such anomalies (consequences of detection and establishment of abuse of procedural rights), and in another - the phenomenon that shows the presence of deviations from the essence of the rule of law and official consolidation, i.e., the transformation of a legal anomaly into a legally accepted rule of law (written proceedings). Such a policy of the legislator cannot be considered effective in combating negative manifestations in the implementation of procedural rights of the individual but can change the attitude to such legal anomalies and transform them into a common norm of behaviour by distorting the understanding of the content of the law. 


\section{REFERENCES}

1. Oborotov, Yu, Zavalniuk, V, Douduchenko, V, Creativity of common law jurisprudence (Phenix 2015).

2. Izarova, I, 'About Special Double Issue 2-3/2020, Justice Under Covid-19 Pandemic' (2020) 2-3 (7) Access to Justice in Eastern Europe 4-5.

3. Rozhnov, O, 'Towards Timely Justice in Civil Matters Amid the COVID-19 Pandemic' (2020) 2-3 (7) Access to Justice in Eastern Europe 100-114.

4. Kaplina, O, Sharenko, S, 'Access to Justice in Ukrainian Criminal Proceedings During the COVID-19 Outbreak' (2020) 2/3 (7) Access to Justice in Eastern Europe 115-133 and others.

5. Zriachkin, A, 'Nihilism in law: causes and ways of solution' (PhD thesis, Saratov 2007) 11.

6. Kravtsov, SO, 'Some aspects of abuse of procedural rights in enforcement proceedings' (2019) 6 Legal scientific electronic journal 121-125.

7. Kravtsov, SA, 'Abuse of procedural rights by the parties to enforcement proceedings: Theoretical and practical aspects' (2018) 4 Bulletin of the civil process 174-206.

8. Gajda-Roszczynialska,K, 'Abuse of procedural rights in Polish and European civil procedure law and the notion of private and public interest' (2019) 2 (3) Access to Justice in Eastern Europe 53-85.

9. Izarova, I, Korotenko, T, 'Prevention of Procedural Rights Abuse: A New Experience of Ukrainian Judges' Polski Proces Cywilny (Civil Procedure of Poland)' (2019) 1 Access to Justice in Eastern Europe 24-33.

10. Vaskovsky, E, Course of civil procedure, Vol 1 (Izd. No. Bashmakov 1997) 432.

11. Yudin, A, 'Abuse of rights in civil proceedings' (PhD dissertation, SPb. 2009) 49.

12. Tikhomirov, DO, Kharchenko, NP, 'Abuse of law as a deviation of lawful behavior' (2016) 1 Scientific Bulletin of Uzhhorod National University, series: Law 27-28.

13. Lukina, l,'Abuse of procedural rights in the civil process of Ukraine. Problems of civil law and process: materials of scientific practice' in conf. dedicated in memory of Prof. OA Pushkin (22 May 2010) (University of Internal Affairs 2010) 363.

14. Korol, OD, 'Prevention of abuse of procedural rights and encouragement of the parties to conscientious behavior' (2020) 19 (1) University scientific notes. Khmelnytsky 117-127. DOI: https://doi.org/10.37491/UNZ.73.10.

15. Kravtsov, S, 'Enforcement proceedings as a final part of the trial in the light of the case law of the European Court of Human Rights and counteraction to abuse of procedural rights of participants in enforcement proceedings' (2020) 112 Bulletin of Taras Shevchenko National University of Kyiv. Legal sciences 36-43. DOI: https: doi.org/10.17721/17282195/2020/1.112-7.

16. Luspenyk, DD, 'Abuse of procedural rights: legislation, methods of detection and ways to counteract' (2015) 6 Journal of Civil and Criminal Procedure 150-171.

17. Izarova, IO, Prityka, YuD 'Simplified litigation of civil proceedings of Ukraine: Challenges of the first year of application in judicial practice' (2019) 145 Problems of legality 51-67.

18. Lesko, A, Insignificance of cases of civil jurisdiction as a criterion for their consideration in simplified claim proceedings and refusal to open cassation proceedings' High Council of Justice, Kyiv, 30 November 2017, <http://www.vru.gov.ua/mass_media/998> accessed 14 September 2021. 
19. Uhrynovska, Ol 'Simplified claim proceedings: Features of legislative regulation' in Minor disputes: European and Ukrainian experience of resolution: coll. Science, etc., participants of the international scientific-practical conf., Kyiv, 23-24 November 2018 (Kyiv 2018) 187-192.

20. Izarova, I, Fleiszar, R, Vebraite, V, 'Access to Justice in Small Claims Procedure: Comparative Study of Civil Procedure in Lithuania' (2019) 9 (1) Poland and Ukraine International Journal of Procedural Law 97-117.

21. Korol, DA, 'Simplified civil proceedings in different European countries: a comparative description' (2020) 1 Journal of Kyiv University of Law 225-228. DOI: 10.36695 / 22195521.1.2020.45.

22. The Law of Ukraine 'On Amendments to the Commercial Procedure Code of Ukraine, Civil Procedure Code of Ukraine, Code of Administrative Procedure of Ukraine and other legislative acts' No 2147-VIII [2017] Vidomosti of the Verkhovna Rada 48/436 <Musiyaka, $M$, Zayets, A, Tsuvina, T, Sushchenko, V, et al, 'The root causes to the non-enforcement of domestic judicial decisions in Ukraine' (2020) 3-4 National security and defense 2.

23. Tsuvina, TA, 'Unity of judicial practice as an element of legal certainty: the approach of the European Court of Human Rights' (2019) 146 Problems of law 63-74. DOI: https://doi. org/10.21564/2414-990x.146.175598

24. Parkhomenko, NM, 'Unity of judicial practice as a component of legal regulation. Theory and history of state and law' (2020) Philosophy of law 26.

25. Resolution of the Commercial Court of Cassation of the Supreme Court of 21 May 2019 in case no $911 / 2817 / 17$ <https://reyestr.court.gov.ua/Review/82068102> accessed 14 September 2021.

26. Resolution of the Civil Court of Cassation of the Supreme Court of 16 August 2018 in case no 711/802/17 <https://reyestr.court.gov.ua/Review/75975948> accessed 14 September 2021.

27. Resolution of the Civil Court of Cassation of the Supreme Court on 06 June 2018 in case no 520/14722/16-ts <https://reyestr.court.gov.ua/Review/74927263> accessed 14 September 2021.

28. Romanyuk, Ja, 'Ensuring the unity of judicial practice by the Supreme Court of Ukraine: the reform needs to be continued' (The newspaper of Ukrainian lawyers 'Legal practice' 15 March 2013) <https://www.viaduk.net/clients/vsu/vsu.nsf/6b6c1e2e6ad3e2fcc225745c0034f4cc/6 d8ae15d52eb146dc2257b71003f884b/\$FILE/5-9_str.pdf> accessed 14 September 2021. 